\title{
"PENGARUH ECONOMIC VALUE ADDED DAN PROFITABILITAS TERHADAP RETURN SAHAM PADA PERUSAHAAN SUBSEKTOR PERDAGANGAN RITEL YANG TERDAFTAR DI BEI PERIODE 2013-2017)"
}

\author{
Yayan Hendayana \\ Nurlina \\ Fakultas Ekonomi dan Bisnis Jurusan Manajemen \\ Universitas Islam As-Syafi'iyah, Jakarta \\ yayan_ha.feb@uia.ac.id
}

\begin{abstract}
This study aims to determine the effect of profitability as measured by Economic Value Added, Return on Assets, and Return on Equity on Stock Returns in retail trading sub-sector companies on the Indonesia Stock Exchange 2013-2017 period. 10 companies have been selected as samples based on predetermined criteria. The approach taken in this research is associative. The data collection technique in this research is the documentation technique. Hypothesis testing uses panel data regression analysis using the Eviews 9 program. Based on the results of the regression coefficient and t-test it shows that partially Economic Value Added and Return on Equity have a significant positive effect on stock returns, while Return on Assets has a significant negative effect on stock returns.
\end{abstract}

\section{Keywords: Economic Value Added, Return on Assets, Return on Equity and Stock Return}

\begin{abstract}
Abstrak : Penelitian ini bertujuan untuk mengetahui pengaruh Profitabilitas yang diukur dengan Economic Value Added, Return on Assets dan Return on Equity terhadap Return Saham pada perusahaan subsektor perdagangan ritel di Bursa Efek Indonesia periode 2013-2017. Terdapat 10 perusahaan yang dipilih sebagai sampel berdasarkan kriteria yang telah ditentukan. Pendekatan yang dilakukan dalam penelitian ini adalah pendekatan asosiatif. Teknik pengumpulan data pada penelitian ini adalah teknik dokumentasi. Pengujian hipotesis menggunakan analisis regresi data panel menggunakan program Eviews 9. Berdasarkan hasil koefisien regresi dan uji t menunjukkan bahwa secara parsial Economic Value Added dan Return on Equity berpengaruh positif dan signifikan terhadap return saham, sedangkan Return on Assets berpengaruh negative dan signifikan terhadap return saham.
\end{abstract}

Kata Kunci : Economic Value Added, Return on Assets, Return on Equity dan Return saham 


\section{PENDAHULUAN}

\subsection{Latar Belakang}

Pasar modal merupakan sarana yang mempertemukan antara pihak yang memiliki kelebihan dana untuk diinvestasikan pada berbagai instrumen dengan pihak yang memnutuhkan dana dengan harapan sama memperoleh keuntungan. Pasar modal berperan besar dan menjadi salah satu indikator bagi kemajuan perekonomian suatu negara. Investor yang ingin memulai investasi atau meningkatkan jumlah investasi pada pasar modal khususnya pada instrument saham harus memiliki perencanaan yang matang. Perencanaan investasi yang matang terkait dengan tingkat resiko juga tingkat return (hasil) yang akan diperoleh. Hokum investasi yang berlaku pada umumnya adalah semakin tinggi tingkat return (hasil) yang diharapkan oleh investor, semakin tinggi pula tingkat risiko yang akan dihadapi oleh investor (high return high risk), begitu juga sebaliknya.

Keuntungan yang diperoleh dari investasi saham di pasar modal melakukan investasi saham di pasar modal adalah berupa capital gain dan dividen. Tetapi disamping hasil yang akan diperoleh terdapat juga risiko yang kemungkinan akan dihadapi yaitu terjadinya capital loss dan tidak diperolehnya dividen. Hasil yang diperoleh (return) dan risiko kerugian (loss) tersebut sangat dipengaruhi oleh berbagai factor terutama kemampuan atau keahlian investor dalam menganalisis berbagai factor atau variable apa saja yang dapat mempengaruhi perubahan harga saham suatu perusahaan. Informasi saham perusahaan mana yang akan memberikan keuntungan atau kerugian bagi investor dapat dilihat dari berbagai faktor yang mempengaruhi pergerakan harga saham tersebut, yaitu faktor internal maupun eksternal salah satunya kinerja atau performa perusahaan yang menurun bisa dilihat melalui Economic Value Added, Return on Assets dan Return on Equity.

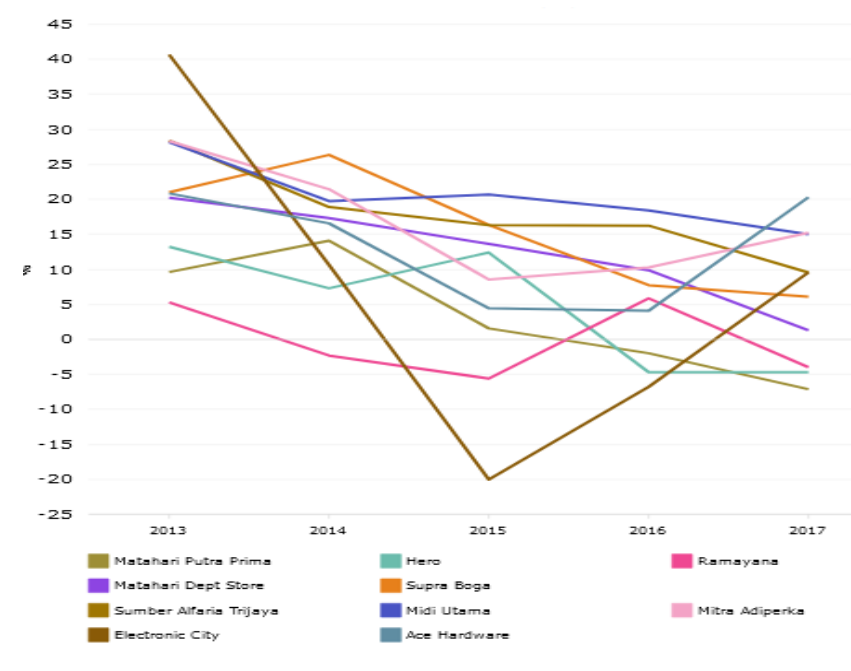

Grafik Pertumbuhan Penjualan Perusahaan Subsektor Ritel 2013-2017

Sumber : databoks.katadata.co.id

Dari data diatas menunjukkan adanya fenomena terjadinya penurunan penjualan selama lima tahun terakhir yang diakibatkan oleh beberapa factor diantaranya tingkat 
persaingan antar perusahaan sejenis atau daya beli masyarakat yang menurun. Dijelaskan oleh Asosiasi Pengusaha Ritel Indonesia (APRINDO), bahwa industri ritel di Indonesia memiliki peran yang cukup besar terhadap pertumbuhan ekonomi Nasional. Perusahaan industri ritel banyak menyerap tenaga kerja, namun dalam beberapa tahun terakhir masih mengalami tekanan karena situasi ekonomi melambat dan pergeseran daya beli masyarakat serta faktor lainnya, yaitu pergeseran bisnis dari cara konvensional ke online, dan biaya produksi (cost production) yang terus mengalami peningkatan. Adanya pengaruh factor eksternal membuat kondisi fundamental terkena dampaknya, sehingga perlu diamati terutama oleh investor maupun calon investor. Dampak fundamental terlihat dari laporan kinerja keuangan diantaranya adalah terkait dengan tingkat profitabilitas perusahaan yang diakibatkan dari penurunan penjualan tersebut. Terjadinya penurunan profitabilitas dapat mempengaruhi harga saham sehingga mengakibatkan penurunan terhadap return yang akan diperoleh investor.

Menurut Suripto (2015:17) Economic Value Added yang positif menandakan perusahaan berhasil menciptakan nilai bagi pasar dan pemilik modal karena perusahaan dapat menghasilkan tingkat pengembalian (return) yang lebih tinggi dibandingkan tingkat biaya modalnya, sehingga perusahaan yang memperoleh laba akan membagikan sebagian keuntungannya berupa dividen kepada investor. Semakin besar laba yang diperoleh perusahaan, maka semakin besar pula dividen yang diperoleh investor. Semakin besar capital gain dan dividen, maka return saham juga akan semakin meningkat.

Menurut Hery (2014:193) bahwa semakin tinggi Return on Assets (ROA) menunjukkan pengembalian atas aset yang tinggi berarti semakin tinggi pula jumlah laba bersih yang dihasilkan dari setiap rupiah dana yang tertanam dalam total aset, sehingga return yang diterima pemegang saham juga akan tinggi. Sementara juga menurut Hery (2014:194) bahwa "Return on Equity (ROE) Semakin tinggi hasil pengembalian atas ekuitas berarti semakin tinggi pula jumlah laba bersih yang dihasilakan dari setiap rupiah dana yang tertanam dalam ekuitas, sehingga return yang diterima pemegang saham juga akan tinggi.

Hasil penelitian Sudityatno dan Suharmanto (2011) menunjukan Return On Asset (ROA) dan Residual Income (RI) berpengaruh positif dan signifikan terhadap return saham, Return on Equity (ROE) berpengaruh negatif dan signifikan terhadap return saham, dan Economic Value Added (EVA) berpengaruh positif tetapi tidak signifikan terhadap return saham. Sementara Hasil penelitian Tyasila (2015) menunjukkan Return on Assets (ROA) dan Price Book to Value (PBV) berpengaruh negatif dan signifikan terhadap return saham. Return on Equity (ROE) dan Earning Per Share (EPS) berpengaruh positif dan signifikan terhadap return saham. Sedangkan Economic Value Added (EVA) dalam penelitian ini diperoleh hasil tidak berpengaruh signifikan terhadap return saham. Secara silmutan Return on Assets (ROA), Return on Equity (ROE), Earning Per Share (EPS), Price Book Value (PBV) dan Economic Value Added (EVA) mempunyai pengaruh signifikan dan positif terhadap return saham.

Berdasarkan uraian diatas dimana tergambar fenomena yang menunjukan terjadinya penurunan kinerja perusahaan sehingga harga saham dan return saham mengalami fluktuasi selama 2013-2017, disamping itu terdapat hasil penelitian terdahulu yang tidak konsisten, maka penelitian ini mengambil judul Pengaruh Economic Value Added dan Profitabilitas Terhadap Return Saham Pada Perusahaan Subsektor Perdagangan Ritel Yang Terdaftar Di BEI Periode 2013-2017). 


\subsection{Permasalahan}

Berdasarkan uraian latar belakang penelitian, maka perumusan masalah dalam penelitian ini adalah :

1. Apakah EVA (Economic Value Added) berpengaruh terhadap return saham Pada Perusahaan Subsektor Perdagangan Ritel Yang Terdaftar Di BEI Periode 2013-2017?

2. Apakah ROA (Return on Assets) berpengaruh terhadap return saham Pada Perusahaan Subsektor Perdagangan Ritel Yang Terdaftar Di BEI Periode 2013-2017?

3. Apakah ROE (Return on Equity) berpengaruh terhadap return saham Pada Perusahaan Subsektor Perdagangan Ritel Yang Terdaftar Di BEI Periode 2013-2017?

\subsection{Tujuan}

Berdasarkan rumusan permasalahan, maka tujuan penelitian adalah untuk :

1. Menganalisis pengaruh Economic Value Added (EVA) terhadap return saham Pada Perusahaan Subsektor Perdagangan Ritel Yang Terdaftar Di BEI Periode 2013-2017.

2. Menganalisis pengaruh Return on Asset (ROA) terhadap return saham Pada Perusahaan Subsektor Perdagangan Ritel Yang Terdaftar Di BEI Periode 2013-2017.

3. Menganalisis pengaruh Return on Equity (ROE) terhadap return saham Pada Perusahaan Subsektor Perdagangan Ritel Yang Terdaftar Di BEI Periode 2013-2017.

\subsection{Manfaat}

1. Bagi investor

Secara teoritis penelitian ini diharapkan dapat menjadi referensi bagi para investor atas informasi perkiraan return saham dan kinerja perusahaan dalam melakukan pengambilan keputusan investasi di pasar modal khususnya pada sector perdagangan ritel yang terdaftar di Bursa Efek Indonesia..

2. Bagi Perusahaan

Secara praktis dapat dijadikan sebagai bahan pertimbangan dan masukan dalam pengambilan keputusan pengembangan perusahaan.

\section{TINJAUAN TEORITIS}

\subsection{Return Saham}

Menurut Tandelilin (2016:102) return saham adalah salah satu faktor yang memotivasi investor berinvestasi dan juga merupakan imbalan atas keberanian investor menanggung risiko atas investasi yang dilakukan.

\subsection{Economic Value Added}

Menurut Suripto (2015:17) Economic Value Added adalah ukuran kinerja keuangan yang paling baik untuk menjelaskan economic profit suatu perusahaan, dibandingkan ukuran lain. 


\subsection{Return on Assets}

Menurut Hery (2014:193) Return on Asset atau hasil pengembalian atas aset menunjukkan seberapa besar kontribusi aset dalam menciptakan laba bersih. Dengan kata lain, rasio ini digunakan untuk mengukur seberapa besar jumlah laba bersih yang akan didapatkan dari setiap rupiah dana yang tertanam dalam total aset.

\subsection{Return on Equity}

Menurut Husnan dan Pudjiastuti (2012:73) Return on Equity adalah rasio yang mengukur seberapa banyak keuntungan yang menjadi hak pemilik modal sendiri.

\subsection{Pengaruh Economic Value Added terhadap Return Saham}

Kinerja manajemen dikatakan baik atau efektif dapat dilihat dari besarnya nilai tambah yang diberikan, maka akan tergambarkan pada peningkatan harga saham. Jika nilai EVA menunjukkan positif berarti ada nilai tambah yang diperoleh perusahaan sehingga menjadikan harga saham juga terus meninggkat. Hal ini membuat investor tertarik untuk berinvestasi di perusahaan dengan nilai EVA yang baik.

H1 : Economic Value Added berpengaruh positif terhadap return saham

\subsection{Pengaruh Return on Asset terhadap Return Saham}

Meningkatnya return on asset (ROA) menunjukkan bahwa perusahaan mampu membukukan laba yang akan memberikan dampak positif bagi para investor untuk mengambil keputusan investasi sehingga harga saham perusahaan meningkat. Harga saham yang meningkat memberikan harapan kepada investor untuk memperoleh keuntungan dari transaksi saham (return saham)

$\mathrm{H} 2$ : Return on Assets berpengaruh positif terhadap return saham

\subsection{Pengaruh Return on Equity terhadap Return Saham}

Semakin besar tingkat laba bersih yang dicapai, maka nilai pengembalian atas modal (ROE) perusahaan pun semakin tinggi, sehingga return yang diterima pemegang saham juga akan tinggi.

H3 : Return on Equity berpengaruh positif terhadap return saham 


\section{Kerangka Pemikiran}

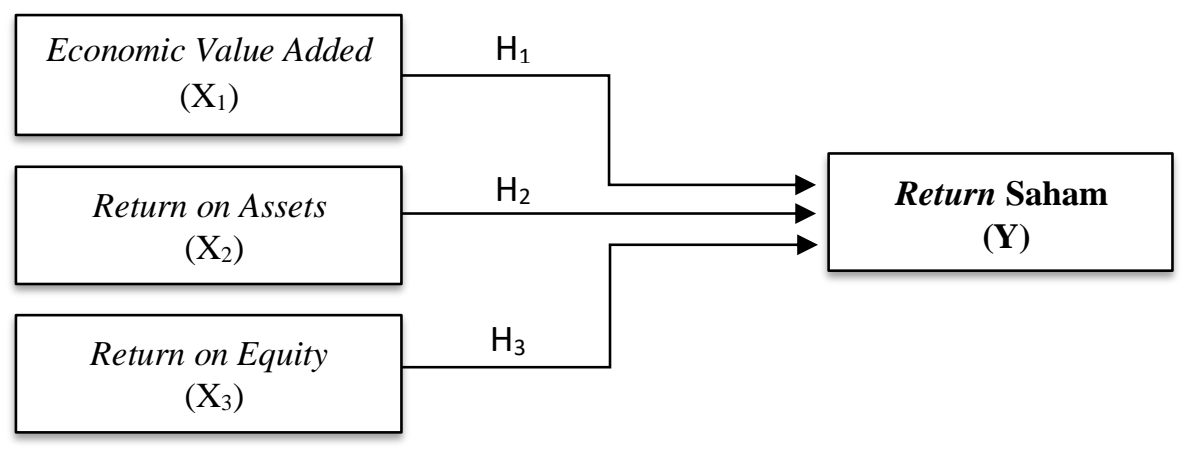

\section{Gambar Kerangka Penelitian}

\section{METODE PENELITIAN}

\subsection{Populasi, Sampel dan Sampling}

Populasi pada penelitian ini adalah perusahaan subsektor perdagangan eceran (ritel) yang tercatat di Bursa Efek Indonesia. sampel yang diteliti adalah perusahaan memenuhi syarat berdasarkan kriteria-kriteria yang telah ditentukan peneliti yaitu sebanyak 10 perusahaan.

Tabel 1. Daftar Perusahaan terpilih sebagai sampel

\begin{tabular}{clll}
\hline No. & Kode & \multicolumn{1}{c}{ Nama Emiten } & $\begin{array}{c}\text { Tanggal } \\
\text { Pencatatan }\end{array}$ \\
\hline 1 & ACES & Ace Hardware Indonesia Tbk & $06 / 11 / 2007$ \\
2 & AMRT & Sumber Alfaria Trijaya Tbk & $15 / 01 / 2009$ \\
3 & CSAP & Catur Sentosa Adiprana Tbk & $12 / 12 / 2007$ \\
4 & HERO & Hero Supermarket Tbk & $02 / 12 / 1989$ \\
5 & LPPF & Matahari Department Store Tbk & $09 / 10 / 1989$ \\
6 & MAPI & Mitra Adiperkasa Tbk & $10 / 11 / 2004$ \\
7 & MIDI & Midi Utama Indonesia Tbk & $30 / 11 / 2010$ \\
8 & MPPA & Matahari Putra Prima Tbk & $21 / 12 / 1992$ \\
9 & RALS & Ramayana Lestari Sentosa Tbk & $24 / 07 / 1996$ \\
10 & SONA & Sona Topas Tourism Industry Tbk & $12 / 07 / 1992$ \\
\hline
\end{tabular}

\subsection{Teknik Pengumpulan Data}

Teknik pengumpulan data adalah dokumentasi yaitu dilakukan dengan mencari data berupa annual report yaitu ringkasan kerja keuangan tahunan perusahaan yang dijadikan sebagai sampel dalam penelitian.

\subsection{Metode Analisis Data}

Untuk menganalisis hubungan antara variabel, pengolahan data dilakukan dengan metode analisis regresi berganda dengan bantuan program Eviews 9.0. Dalam penelitian 
mengunakan data panel yang menggabungkan data cross section yang terdiri 10 perusahaan dan data time series terdiri dari tahun 2013-2017.

\section{HASIL PENELITIAN DAN PEMBAHASAN}

\section{Ringkasan Hasil Pengujian Regresi Data Panel Estimasi Model Return dengan Common Effects ( Cross-section weights)}

Dependent Variabel: RETURN

Method Panel EGLS ( Cross- section weights)

Date: 11/07/20 Time: 11:19

Sample: 20132017

Periods included: 5

Cross-sections included: 10

Total panel (balanced) observations: 50

Linear estimation after one-step weighting matrix

\begin{tabular}{|c|c|c|c|c|}
\hline Variabel & Coefficient & Std. Error & t-Statistic & Prob. \\
\hline $\mathrm{C}$ & 56.02166 & 21.27951 & 2.632657 & 0.0141 \\
\hline EVA & 2.803486 & 1.313007 & 2.135164 & 0.0423 \\
\hline ROA & -2.603605 & 0.924949 & -2.814862 & 0.0092 \\
\hline ROE & 2.943504 & 0.410480 & 7.170877 & 0.0000 \\
\hline \multicolumn{5}{|c|}{ Weighted Statistics } \\
\hline R-squared & 0.907171 & \multirow{5}{*}{\multicolumn{2}{|c|}{$\begin{array}{l}\text { Mean dependent var } \\
\text { S.D. dependent var } \\
\text { Sum squared resid } \\
\text { Durbin-Watson stat }\end{array}$}} & -0.719736 \\
\hline Adjusted R-squared & 0.896460 & & & 3.324415 \\
\hline S.E. of regression & 1.036461 & & & 27.93052 \\
\hline F-statistic & 84.69471 & & & 1.892445 \\
\hline Prob(F-statistic) & 0.000000 & & & \\
\hline \multicolumn{5}{|c|}{ Unweighted Statistics } \\
\hline R-squared & 0.190916 & \multirow{2}{*}{\multicolumn{2}{|c|}{$\begin{array}{l}\text { Mean dependent var } \\
\text { Durbin-Watson stat }\end{array}$}} & 20.15100 \\
\hline Sum squared resid & 39803.10 & & & 1.725947 \\
\hline
\end{tabular}

Sumber: data diolah dengan Eviews 9.

\subsection{Pengaruh Economic Value Added terhadap Return Saham}

Berdasarkan analisis data yang dilakukan, hasil penelitian ini menunjukkan bahwa variabel Economic Value Added berpengaruh positif dan signifikan terhadap return saham. Hasil uji hipotesis diperoleh nilai probabilitas sebesar 0.0423 lebih kecil dari 0.05 atau $\mathrm{t}$-hitung $=2.135164$ lebih besar dari $\mathrm{t}$-tabel $=1.67155$ yang berarti hipotesis pertama (H1) diterima, yaitu Economic Value Added berpengaruh positif dan signifikan terhadap return saham.

Hasil penelitian ini sejalan dengan pendapat Tandelilin (2017:325) bahwa Economic Value Added adalah ukuran keberhasilan manajemen perusahaan dalam meningkatkan nilai tambah (value added) bagi perusahaan. Kinerja manajemen dikatakan baik atau 
efektif dapat dilihat dari besarnya nilai tambah yang diperoleh, maka akan tergambarkan oleh harga saham yang mengalami peningkatan. Jika nilai EVA positif artinya ada nilai tambah yang diperoleh perusahaan sehingga membuat harga saham perusahaan juga terus meningkat. Hal ini membuat investor tertarik untuk berinvestasi di perusahaan dengan nilai EVA yang baik.

\subsection{Pengaruh Return on Assets terhadap Return Saham}

Berdasarkan analisis data yang dilakukan, hasil penelitian ini menunjukkan bahwa variabel Return on Assets diketahui berpengaruh negatif dan signifikan terhadap return saham. Hasil uji hipotesis diperoleh nilai probabilitas 0.0092 lebih kecil dari 0.05 atau $\mathrm{t}$-hitung $=-2.814862$ lebih kecil dari $\mathrm{t}$-tabel $=1.67155$ Hasil penelitian ini tidak sesuai dengan hipotesis penelitian bahwa ROA berpengaruh positif terhadap return saham. Hal ini menunjukkan bahwa pengelolahaan perusahaan kurang efisien sehingga investor menilai kinerja perusahaan kurang baik dan menyebabkan harga saham menjadi turun dan kemudian berdampak return saham yang ikut menurun.

\subsection{Pengaruh Return on Equity terhadap Return}

Berdasarkan analisis data yang dilakukan, hasil penelitian ini menunjukkan bahwa variabel Return on Equity diketahui berpengaruh positif dan signifikan terhadap return saham. Hasil uji hipotesis diperoleh nilai probabilitas sebesar 0.0000 lebih kecil dari 0.05 atau $\mathrm{t}$-hitung $=7.170877$ lebih besar dari $\mathrm{t}_{\text {-tabel }}=1.67155$ berarti hipotesis ketiga $(\mathrm{H} 3)$ diterima, yaitu Return on Equity berpengaruh positif dan signifikan terhadap return saham.

Hasil penelitian ini sejalan dengan pendapat Hery (2014:194) menyatakan bahwa Return on Equity digunakan untuk mengukur kinerja manajemen perusahaan dalam mengelola modal yang ada untuk menghasilkan laba bersih. Semakin besar tingkat laba bersih yang dicapai, maka nilai ROE perusahaan pun semakin tinggi, sehingga return yang diterima pemegang saham juga akan tinggi.

\section{PENUTUP}

\subsection{Simpulan}

Berdasarkan hasil pengujian hipotesis dapat diperoleh kesimpulan sebagai berikut :

1. Economic Value Added (EVA) bepengaruh positif signifikan terhadap return saham Pada Perusahaan Subsektor Perdagangan Ritel Yang Terdaftar Di BEI Periode 20132017

2. Return on Assets (ROA) bepengaruh negatif signifikan terhadap return saham Pada Perusahaan Subsektor Perdagangan Ritel Yang Terdaftar Di BEI Periode 2013-2017.

3. Return on Equity (ROE) berpengaruh positif dan signifikan terhadap return saham Pada Perusahaan Subsektor Perdagangan Ritel Yang Terdaftar Di BEI Periode 20132017. 


\subsection{Saran}

Berdasarkan kesimpulan di atas, saran yang diharapkan yang dapat menjadi masukkan yang berguna, sebagai berikut:

1. Bagi investor, yang ini berinvestasi pada saham dan mengharapkan return berupa capital gain hendaknya mempertimbangkan Economic Value Added, Return on Assets dan Return on Equity yang terbukti memiliki pengaruh signifikan terhadap hasil investasi (return).

2. Hasil penelitian ini belum tentu dapat digeneralisasikan pada sektor lain sehingga disarankan pada peneliti selanjutnya untuk memperluas ruang lingkup penelitian lebih luas lagi terhadap sektor lainnya yang ada di Bursa Efek Indonesia. Penelitian ini juga hanya menggunakan variabel EVA dan profitabilitas yang diukur dengan ROA, dan ROE saja sehingga disarankan juga untuk meneliti variable-variabel lain yang dapat mempengaruhi return saham.

\section{REFERENSI}

Alexander, Nico. dan Destriana, Nicken. 2013. Pengaruh Kinerja Keuangan Terhadap Return Saham. Jurnal Bisnis dan Akuntansi. 15(2):123-132.

Basuki, Agus Tri. dan Prawoto, Nano. 2016. Analisis Regresi Dilengkapi Aplikasi SPSS dan Eviews. PT Rajagrafindo Persada. Depok.

Brigham, Eugene F. dan Houston, Joel F. 2010. Dasar-Dasar Manajemen Keuangan Essentials of Financial Management. Edisi 11. Salemba Empat. Jakarta.

Darmadji, Tjiptono. dan Fakhruddin, Hendy M. 2012. Pasar Modal di Indonesia Pendekatan Tanya Jawab. Edisi 3. Salemba Empat. Jakarta.

Fahmi, Irham. 2013. Rahasia Saham dan Obligasi Stategi Meraih Keuntungan Tak Terbatas dalam Bermain Saham dan Obligasi. Alfabeta. Bandung.

Fahmi, Irham. 2015. Manajemen Risiko Teori Kasus dan Solusi. Alfabeta. Bandung.

Fahmi, Irham. 2015. Pengantar Manajemen Keuangan Teori dan Soal Jawab. Alfabeta. Bandung.

Gunadi, Gd Gilang. dan Kesuma, I Ketut Wijaya. 2015. Pengaruh ROA, DER, EPS Terhadap Return Saham Perusahaan Food and Beverage BEI. E-Jurnal Manajemen Unud. 4(6):1636-1647.

Hartono, Jogiyanto. 2017. Teori Portofolio dan Analisis Investasi. Edisi 11. BPFE. Yogyakarta.

Hery. 2014. Analisis Kinerja Manajemen. PT Grasindo. Jakarta.

Husnan, Suad. dan Pudjiastuti, Enny. 2012. Dasar-dasar Manajemen Keuangan. Edisi 6. UPP STIM YKPN. Yogyakarta.

Kasmir. 2012. Analisis Laporan Keuangan. PT. Rajagrafindo Persada. Jakarta.

Keown, Arthur J. Martin, John D. Petty, J William. dan JR, David F Scott. 2010. Manajemen Keuangan Prinsip dan Penerapan. Edisi 10 Jilid 2. PT Indeks. Jakarta. 
Octavera, Sari. Putri, Siska Lusia. dan Abdilla, Mohammad. 2016. Analisis Pengaruh Penilaian Kinerja Keuangan dengan Menggunakan Metode Tradisional (DER,ROA) dan Metode Konsep Baru (EVA) Terhadap Return Saham ( Studi Kasus pada Perusahaan Industri Keuangan Non Bank yang Listing di BEI. Jurnal Ekonomi dan Bisnis Dharma Andalas. 18(1): 138-159.

Purnama, Isya. 2014. Pengaruh Return on Assets (ROA), Return on Equity (ROE) dan Economic Value Added (EVA) Terhadap Return Saham. Skripsi. Fakultas Ekonomi Universitas Widyatama, Bandung.

Puspitadewi, Cokorda Istri Indah. dan Rahyuda, Henny. 2016. Pengaruh DER, ROA dan EVA Terhadap Return Saham pada Perusahaan Food and Beverage di BEI. EJurnal Manajemen Unud. 5(3): 1429-1456.

Simatupang, Mangasa. 2010. Pengetahuan Praktis Investasi Saham dan Reksa Dana. Mitra Wacana Media. Jakarta.

Sudityatno, Bambang. dan Suharmanto, Toto. 2011. Keuangan Konvensional, Economic Value Added dan Return Saham. Jurnal Dinamika Manajemen. 2(2):153-161.

Sugiyono. 2016. Metode Penelitian Kuantitatif, Kualitatif dan R\&D. Alfabeta. Bandung.

Sujarweni, V Wiratna. 2015. Metodologi Penelitian Bisnis dan Ekonomi. PT Pustaka Baru. Yogyakarta.

Suripto. 2015. Manajemen Keuangan Strategi Penciptaan Nilai Perusahaan Melalui Pendekatan Economic Value Added. Graha Ilmu. Yogyakarta.

Susilowati, Yeye. dan Turyanto, Tri. 2011. Reaksi Signal Rasio Profitabilitas dan Rasio Solvabilitas Terhadap Return Saham Perusahaan. Dinamika Keuangan dan Perbankan. 3(1):17-37.

Sasongko, Heru. 2016. Analisis Pengaruh Economi Value Added (EVA), Market Value Added (MVA) dan Return on Assets (ROA) Terhadap Return Saham, pada Perusahaan Perbankan yang Terdaftar di BEI. Skripsi. Fakultas Ekonomi Universitas Islam As-Syafi' iyah, Jakarta.

Sutedi, Adrian. 2013. Pasar Modal Mengenal Nasabah Sebagai Pencegahan Pencucian Uang. Alfabeta. Bandung.

Tandelilin, Eduardus. 2016. Portofolio dan Investasi Teori dan Aplikasi. Edisi 1. Kanisius Anggota IKAPI. Yogyakarta.

Tandelilin, Eduardus. 2017. Pasar Modal Manajemen Portofolio dan Investasi. PT Kanisius Anggota IKAPI. Yogyakarta.

Tumonggor, Mutiara. Murni, Sri. dan Rate, Paulina Van. 2017. Analisis Pengaruh Current Ratio, Return on Equity, Debt to Equity dan Growth Terhadap Return Saham pada Cosmetics and Household industry yang Terdaftar di BEI. Jurnal EMBA. 5(2):2203-2210.

Tyasila, Utami Ning. 2015. Pengaruh Rasio Kinerja Keuangan Terhadap Return Saham Sektor Perbankan yang Terdaftar di BEI. Skripsi. Fakultas Ekonomi dan Bisnis Universitas Muhammadiyah, Surakarta.

Wati, Lela Nurlaela. 2017. Metodologi Penelitian Terapan Aplikasi SPSS, Eviews, Smart PLS dan AMOS. CV Mujahid Press. Bandung. 
Wau, Redaktur. Syariffuddin, Achmad. dan Herwanto, Rudi. 2017. Analisis Perbandingan Economic Value Added (EVA) dan Return on Investment (ROI) dalam Menilai Kinerja Keuangan Sub Sektor Farmasi yang Terdaftar di BEI. Journal of Business Studies. 2(1):99-109.

Website Bursa Efek Indonesia. www.idx.co.id, diakses September 2019.

Website sahamok.com, diakses September 2019.

https://databoks.katadata.co.id/datapublish/2018/04/18/2013-2017-pertumbuhanpenjualan-emiten-ritel-turun 